\title{
PENGEMBANGAN MODUL ELEKTRONIK BERBASIS EDUCATION FOR SUSTAINABLE DEVELOPMENT MENGGUNAKAN FLIP PDF PROFESSIONAL PADA MUATAN PELAJARAN IPA TEMA LINGKUNGAN SAHABAT KITA UNTUK SISWA KELAS V
}

\author{
N.L.P.W. Pratiwi ${ }^{1}$, N. Dantes $^{2}$, D.G.H. Divayana ${ }^{3}$ \\ ${ }^{123}$ Program Studi Pendidikan Dasar \\ Universitas Pendidikan Ganesha \\ Singaraja, Indonesia \\ e-mail: pitri.widi@undiksha.ac.id ${ }^{1}$, dantes@undiksha.ac.id ${ }^{2}$, \\ hendra.divayana@undiksha.ac.id ${ }^{3}$
}

\begin{abstract}
Abstrak
Penelitian ini bertujuan untuk: 1) mendeskripsikan unsur-unsur dari tahapan pengembangan, 2) mengetahui dan mendeskripsikan validitas, serta 3) mengetahui dan mendeskripsikan kepraktisan modul elektronik berbasis Education for Sustainable Development menggunakan flip PDF professional pada muatan pelajaran IPA tema lingkungan sahabat kita untuk siswa kelas V. Pengembangan modul elektronik ini dilaksanakan dengan model ADDIE pada tahap analyze, design, development, dan evaluation. Subjek penelitian adalah 2 ahli materi pembelajaran, 2 ahli desain dan media pembelajaran, 2 ahli kepraktisan, 10 guru kelas $V$ di Kecamatan Denpasar Utara, 87 siswa kelas V di SD Negeri 5 Tonja. Data validitas expert dikumpulkan menggunakan angket validasi ahli yang dianalisis dengan Gregory dan Persentase, data validitas empirik dikumpulkan menggunakan angket respon guru dianalisis dengan Product Moment dan Mean observasi, serta data kepraktisan dikumpulkan menggunakan angket respon siswa dianalisis dengan Mean observasi. Hasil analisis data menunjukkan bahwa: 1) seluruh instrumen mendapatkan nilai 1,0 pada kategori sangat tinggi, penilaian produk ahli materi mendapatkan rerata persentase $97,14 \%$, penilaian produk ahli desain mendapatkan rerata persentase $97 \%$, dan penilaian produk ahli media mendapatkan rerata persentase $95,33 \%$. Seluruh pernyataan pada angket respon guru memiliki nilai $r_{\text {hitung }}$ lebih besar dari $r_{\text {tabel }}$ serta Mean observasi memperoleh nilai 328,3 pada kategori sangat layak; 2) perhitungan Mean observasi dari hasil angket respon siswa memperoleh nilai sebesar 174,64 pada kategori sangat praktis. Dapat disimpulkan bahwa penelitian ini menghasilkan modul elektronik yang valid dan praktis.
\end{abstract}

Kata kunci: Education for Sustainable Development; Flip PDF Professional; Modul Elektronik

\begin{abstract}
This study aimed to:1) describe the elements of development steps, 2) find out and describe the validity, and 3) find out and describe the practicality an electronic module based on Education for Sustainable Development using flip PDF professional on the science lesson the theme of our friend's environment for fifth grade students. The development of this electronic module was carried out with the steps ADDIE of analysis, design, development, and evaluation. The subjects in this study were 2 learning material experts, 2 design experts and instructional media, 2 practicality experts, 10 fifth grade teachers in North Denpasar District, 87 students of the fifth grade at SD Negeri 5 Tonja. Expert validity data were collected by using validation questionnaire which was analyzed using Gregory and percentage, empirical data validity were collected by teachers responses questionnaire which was analyzed using Product Moment and Mean observation, then data practicality were collected using students responses questionnaire which was analyzed using Mean observation. The results showed that: 1) all instruments was 1,0 which was considered as very high category, the average result of assessment of learning material experts products was $97,14 \%$, the average of assessment of learning design expert products was of $97 \%$, and the product assessments learning media experts resulting 95,33\%. The assessment of the teacher's responses showed that all statement items in the assessment $r_{\text {hitung }}$ are greater than $r_{\text {tabel }}$ and Mean observation was 328,3 in the very feasible category; 2) Mean observation from the results of the student response questionnaire assessment
\end{abstract}


obtained 174,64 in the very practical category. It could be concluded the present research resulting valid and practical electronic module.

Keywords: Education for Sustainable Development; Flip PDF Professional; Electronic Module

\section{PENDAHULUAN}

Perkembangan ilmu pengetahuan dan teknologi yang semakin pesat pada abad 21 saat ini membawa berbagai perubahan, sehingga diperlukan penataan komprehensif pada kualitas pendidikan, sebab pendidikan memberikan kontribusi besar bagi terciptanya sumber daya manusia, menjadikan generasi penerus bangsa yang mampu bersaing sesuai kebutuhan dalam masyarakat serta dunia kerja. Maka, berdasarkan hal tersebut, untuk membangun pendidikan abad 21 perlu dirancang suatu pembelajaran sains yang efektif bagi siswa, karena hal itu membantu siswa mengembangkan keterampilan berpikir kritis, kreatif, membentuk penguasaan konsep dasar, berpikir ilmiah, membangun percaya diri, serta memecahkan masalah (Windyariani, 2019). Sains adalah upaya sistematis dalam menciptakan, membangun, dan mengorganisasikan pengetahuan untuk memahami alam semesta. Pembelajaran sains dapat juga disebut pembelajaran IImu Pengetahuan Alam (IPA), sebab IPA juga berkaitan dengan upaya memahami alam secara sistematis, karena tidak hanya penguasaan pengetahuan berupa fakta, konsep, atau prinsip, tetapi juga proses penemuan. Melalui pembelajaran IPA terpadu siswa dapat diarahkan berpikir luas dan mendalam untuk menangkap dan memahami hubungan konseptual, sehingga siswa akan terbiasa untuk berpikir secara terarah, teratur, utuh, dan menyeluruh.

Peringkat PISA (Programme for International Student Assesment) tahun 2018 memposisikan Indonesia pada kategori kinerja sains di urutan 70 dari 78 negara dengan skor 396 (OECD, 2018) yang menunjukkan bahwa, pengetahuan dan pemahaman konsep IPA siswa di Indonesia masih berada di bawah ratarata serta menyatakan jika pembelajaran IPA belum dilaksanakan secara optimal. Salah satu faktor yang diduga menjadi pengaruh adalah penggunaan bahan ajar. Seperti yang diungkapkan oleh Sugiyanto (Avikasari \& Indriayu, 2018) jika salah satu faktor yang dapat mempengaruhi rendahnya prestasi belajar siswa dalam pembelajaran IPA adalah minimnya referensi atau bahan ajar sebagai sarana menunjang pembelajaran. Bahan ajar yang sesuai diimplementasikan dalam situasi saat ini adalah bahan ajar berbasis teknologi. Bahan ajar berbasis teknologi dikatakan sebagai bahan ajar bersifat interaktif dan berkategori high tech.

Berdasarkan hasil dari wawancara yang dilakukan di SD Negeri 5 Tonja Denpasar, ditemukan fakta jika guru memahami pentingnya pemanfaatan teknologi dalam pembelajaran, namun tidak disertai dengan mengoptimalkan kemampuan diri untuk dapat membuat bahan ajar berbasis teknologi yang memuat komponen materi IPA secara mendalam. Bahan ajar yang dominan digunakan oleh guru masih sebatas buku cetak yang diterbitkan pemerintah dan juga LKS. Sekolah yang bersangkutan merupakan salah satu sekolah adiwiyata dan telah memasukkan pendidikan berorientasi lingkungan ke dalam kurikulum, namun belum tercermin pada materi pembelajaran di dalam kelas.

Maka, dipandang perlu adanya suatu upaya untuk mengembangkan bahan ajar yang memuat materi IPA secara mendalam dan mencerminkan pendidikan berorientasi lingkungan. Bahan ajar yang relevan untuk dapat dikembangkan adalah modul elektronik. Modul elektronik adalah suatu bahan ajar non cetak yang dapat digunakan untuk belajar secara mandiri oleh siswa dengan memanfaatkan perangkat komputer (Haspen \& Festiyed, 2019). Sehingga kelebihan modul elektronik adalah sifatnya interaktif, mampu menampilkan multimedia, dapat membiasakan siswa belajar mandiri serta memanfaatkan alat teknologi dan informasi. 
Salah satu materi IPA di sekolah dasar yang dekat dengan kehidupan nyata siswa adalah siklus air. Air merupakan isu yang harus dibahas dalam pembelajaran, karena sumber daya alam penting untuk keberlangsungan hidup masa depan. Untuk mengoptimalkan pemahaman konsep IPA dan pendidikan berorientasi lingkungan, maka siswa harus memiliki pengetahuan pengelolaan, pemanfaatan, dan pelestarian air sebagai salah satu dari sumber daya alam yang ada di bumi. Oleh karena itu, materi pada modul elektronik ini dapat dipadukan dengan konsep Education for Sustainable Development, karena merupakan sebagai gagasan yang berasal dari pendidikan lingkungan. Tujuan paling penting dari pendidikan lingkungan adalah membentuk manusia dengan kemampuan sains yang baik, peduli pada masalah berkaitan dengan lingkungan dan mampu bertindak untuk dapat menjaga lingkungan.

\section{Education for Sustainable}

Development adalah pendekatan terhadap pengajaran yang didasarkan pada prinsip keberlanjutan dalam rangka memberikan pendidikan berkualitas dan meningkatkan pembangunan manusia (KNIU, 2014). Konsep Education for Sustainable Development yakni konsep memasukkan isu-isu kunci pembangunan berkelanjutan dalam pembelajaran, sehingga siswa dapat memiliki nilai, pengetahuan, dan keterampilan keberlanjutan untuk dapat mempertahankan kelestarian lingkungan agar dimanfaatkan oleh manusia dan makhluk bumi di masa akan datang.

Konsep Education for Sustainable Development memiliki tiga perspektif diantaranya sosial budaya, lingkungan, dan ekonomi (Indrati \& Hariadi, 2016). Pemahaman berkaitan dengan perspektif sosial budaya adalah pemahaman tentang sistem sosial dan peran manusia pada perkembangan. Kemudian, pemahaman berkaitan dengan perspektif lingkungan tentang sumber daya alam, lingkungan alam, dan dampak kegiatan manusia. Pemahaman terkait dengan perspektif ekonomi adalah kepekaan pada keterbatasan dan juga potensi dari pertumbuhan ekonomi.
Adanya kemajuan pada ilmu pengetahuan dan teknologi dalam bidang pendidikan pada saat ini, tentu diharapkan dapat memberikan kemudahan berbagai akses khususnya pada pembelajaran. Seiring dengan terjadinya perkembangan tersebut, terdapat istilah multimedia yang banyak digunakan dalam melaksanakan kegiatan pembelajaran saat ini. Melalui kegiatan dengan lebih memanfaatkan multimedia, ditemui bahwa pembelajaran yang tercipta akan dapat menjadi lebih bermakna bagi siswa.

Agar tercipta sebuah bahan ajar yang berbasis teknologi dan bermuatan multimedia, maka modul elektronik yang dipadukan dengan konsep Education for Sustainable Development dapat dibuat menggunakan program aplikasi yaitu flip PDF professional. Dengan flip PDF professional memungkinkan guru untuk membuat dan mengkreasikan bahan ajar dengan berbagai efek interaktif yang tentunya penggunaan bahan ajar akan menjadi menarik, praktis, dan fleksibel.

Salah satu penelitian menunjukkan hasil uji validitas terhadap bahan ajar elektronik dengan menggunakan flip PDF professional pada materi alat-alat optik oleh validator ahli dan praktisi menghasilkan persentase rata-rata $79,45 \%$ yang dikategorikan sangat valid (Sriwahyuni et al., 2019). Perbedaan penelitian tersebut dengan penelitian ini adalah materi yang disampaikan dalam bahan ajar elektronik tidak berdasarkan pendekatan saintifik. Sedangkan, pada penelitian ini materi atau tugas dalam modul elektronik dipadukan dengan aspek dari pendekatan konsep Education for Sustainable Development yang merujuk pendekatan saintifik karena siswa diarahkan melakukan aktivitas belajar yang memungkinkan mengkritisi dan mengemukakan pikiran pada persoalan.

Selanjutnya, penelitian lain menunjukkan bahwa modul berbasis Education for Sustainable Development pada konsep ekologi untuk siswa SMA kelas $\mathrm{X}$ sangat layak digunakan (Rahman et al., 2019). Kendala yang ditemui dari hasil penelitian adalah sebanyak $66,7 \%$ guru belum mengetahui konsep Education 
for Sustainable Development. Maka dari itu, penelitian ini sangat berkonstribusi karena akan semakin banyak guru mengetahui konsep Education for Sustainable Development. Perbedaan penelitian tersebut dengan penelitian ini adalah belum terdapat sumber pada teks informasi yang disajikan dalam modul. Di samping itu, modul cetak tentunya membutuhkan waktu dalam memperbanyaknya. Sedangkan, pada penelitian ini setiap teks informasi yang disajikan telah dicantumkan sumber pada bagian bawah dan lebih efisien waktu karena berbentuk elektronik.

Berdasarkan uraian yang telah dipaparkan tersebut, maka adapun bahan ajar yang akan dikembangkan dalam penelitian ini adalah modul elektronik berbasis Education for Sustainable Development menggunakan flip PDF professional pada muatan pelajaran IPA tema Lingkungan Sahabat Kita untuk siswa kelas V.

Tujuan penelitian ini adalah (1) untuk mendeskripsikan unsur-unsur dari tahapan pengembangan modul elektronik berbasis Education for Sustainable Development menggunakan flip PDF professional pada muatan pelajaran IPA tema lingkungan sahabat kita untuk siswa kelas V, (2) untuk mengetahui dan mendeskripsikan validitas modul elektronik berbasis Education for Sustainable Development menggunakan flip PDF professional pada muatan pelajaran IPA tema lingkungan sahabat kita untuk siswa kelas $\mathrm{V}$, dan (3) untuk mengetahui dan mendeskripsikan kepraktisan modul elektronik berbasis Education for Sustainable Development menggunakan flip PDF professional pada muatan pelajaran IPA tema lingkungan sahabat kita untuk siswa kelas V.

\section{METODE PENELITIAN}

Penelitian ini merupakan jenis penelitian dan pengembangan atau dapat disebut Research and Development (R\&D). Model pengembangan yang digunakan adalah model ADDIE singkatan dari Analyze, Design, Development, Implementation, dan Evaluation. Menurut tahapan-tahapan pengembangan produk, model ADDIE dinyatakan lebih rasional dan lengkap. Pada penelitian ini, (1) tahap analyze dilaksanakan dengan melakukan pengumpulan data dan juga informasi berkaitan dengan permasalahan yang hendak diteliti, (2) tahap design terfokus dalam merancang storyboard modul elektronik dan instrumen, (3) tahap development merupakan langkah untuk membuat modul elektronik dengan menggunakan sumber yang relevan dan melakukan validasi instrumen, (4) tahap implementation tidak dapat dilaksanakan karena keterbatasan waktu, dan (5) tahap evaluation menilai keseluruhan dari tahapan pengembangan yang dilakukan.

Subjek yang dilibatkan pada penelitian ini antara lain 2 ahli materi pembelajaran, 2 ahli desain dan media pembelajaran, 2 ahli kepraktisan, 10 guru kelas $\mathrm{V}$ di wilayah Kecamatan Denpasar Utara, dan 87 siswa di SD Negeri 5 Tonja Denpasar Tahun Pelajaran 2020/2021.

Untuk dapat mengukur data dalam penelitian, instrumen yang digunakan antara lain (1) angket validasi produk ahli materi pembelajaran, (2) angket validasi produk ahli desain pembelajaran, (3) angket validasi produk ahli media pembelajaran, (4) angket respon guru, dan (5) angket respon siswa. Sebelum dapat digunakan, seluruh instrumen tersebut dilakukan uji validasi terlebih dahulu oleh ahli, kecuali angket respon guru karena merupakan gabungan dari angket validasi produk ahli materi pembelajaran, ahli desain pembelajaran, dan ahli media pembelajaran. Komponen dari penilaian modul elektronik berbasis Education for Sustainable Development menggunakan flip PDF professional pada muatan pelajaran IPA tema lingkungan sahabat kita untuk siswa kelas V diadaptasi dari penilaian BSNP (dalam Zulfahri, 2019) terkait dengan penilaian buku teks diantaranya kelayakan isi, komponen penyajian, penilaian bahasa, dan kelayakan kegrafikan. Nantinya, produk berupa modul elektronik yang dihasilkan dapat dikatakan memiliki kualitas yang baik jika telah memenuhi nilai dari validitas dan kepraktisan. 
Jurnal Teknologi Pembelajaran Indonesia

ISSN: 2615-2797 (Print) | ISSN:2614-2015 (Online)

DOI : 10.23887/jurnal_tp.v11i2.661 Volume 11 Nomor 2 Tahun 2021

Pada penelitian ini, untuk dapat menghitung validitas isi masing-masing instrumen yang telah divalidasi oleh para ahli menggunakan rumus Gregory (Candiasa, 2011) berikut.

$$
V=\frac{D}{A+B+C+D}
$$

Keterangan:

V : Validitas Isi

A : Sel menunjukkan ketidaksetujuan dari kedua penilai

B dan C : Sel menunjukkan perbedaan pandangan antara pakar

D : Sel yang menunjukkan persetujuan yang valid antara kedua pakar

Setelah diperoleh hasil validasi instrumen, selanjutnya dilakukan validasi terhadap produk oleh ahli dengan rumus persentase Riduwan dan Akdon (Apsari \& Rizki, 2018) sebagai berikut.

Persentase $=\frac{\text { jumlah skor yang diberikan validator }}{\text { skormaksimal ideal }} \times 100 \%$

Hasil persentase yang diperoleh dari masing-masing ahli selanjutnya dihitung rerata persentase keseluruhan dengan rumus sebagai berikut.

$$
\text { Rerata Persentase }=\frac{\sum P}{N}
$$

Keterangan:

$\sum P=$ jumlah persentase keseluruhan subjek $\mathrm{N}$ = banyak subjek

Hasil rerata persentase di atas dikategorikan sesuai dengan Criterion Referenced Evaluation atau Penialain Acuan Patokan (PAP) pada tabel berikut.

Tabel 1. Pedoman Penilaian Acuan Patokan (PAP)

\begin{tabular}{cc}
\hline Rentangan Persentil (\%) & Kategori \\
\hline $90-100$ & Sangat Layak \\
$80-89$ & Layak \\
$65-79$ & Cukup Layak \\
$40-64$ & Kurang Layak \\
$0-39$ & Sangat Kurang Layak \\
\hline
\end{tabular}

(Dantes, 2017)

Kemudian, untuk mengukur validitas empirik pada penelitian ini melalui hasil penyebaran angket respon guru dilakukan dengan menghitung Product Moment dan juga Mean observasi yang selanjutnya dikonfersikan ke dalam tabel kategori PAIT. Rumus Product Moment adalah sebagai berikut.

$$
r_{x y}=\frac{N \sum X Y-\left(\sum X\right)\left(\sum Y\right)}{\sqrt{\left.\left\{N \sum X^{2}-\left(\sum X\right)^{2}\right\} N \sum Y^{2}-\left(\sum Y\right)^{2}\right\}}}
$$

(Sugiyono, 2015)

Keterangan:

$r_{x y}=$ korelasi antara skor butir dengan skor total

$\mathrm{X}=$ skor dari variable $\mathrm{X}$ (skor butir)

$Y=$ skor dari variable $Y$ (skor total)

$\mathrm{N}$ = banyaknya responden
Apabila $r_{x y}$ positif dan lebih besar dari $r_{\text {tabel }}$, maka butir pernyataan dapat dinyatakan valid, sedangkan jika $r_{x y}$ lebih kecil dari $r_{\text {tabel }}$ maka butir pernyataan dinyatakan tidak valid.

Setelah perhitungan tersebut diperoleh, kemudian dapat dilanjutkan dengan melakukan analisis data untuk menguji validitas produk menggunakan rumus Mean observasi yaitu sebagai berikut.

$$
\mathrm{M}=\frac{\sum f X}{N}
$$

(Ananda \& Fadhli, 2018)

Keterangan :

$\mathrm{M}=$ nilai rata-rata atau Mean observasi

$\sum \mathrm{f} X=$ jumlah skor seluruh responden

$N$ = banyaknya responden 
Perolehan skor dari masing-masing guru dijumlahkan berdasarkan angket respon gutu, selanjutnya dirata-ratakan untuk memperoleh hasil validitas empirik dari produk dengan membandingkan nilai rata-rata ke tabel pengkonfersian kategori PAIT (Penilaian Acuan Ideal Teoritik) pada tabel berikut.

Tabel 2. Kategori PAIT

\begin{tabular}{cll}
\hline No & Kategori PAIT & Keterangan \\
\hline 1 & $\mathrm{Mi}+1,5 \mathrm{SDi}-\mathrm{Mi}+3 \mathrm{SDi}$ & Sangat Layak \\
2 & $\mathrm{Mi}+0,5 \mathrm{SDi}-\mathrm{Mi}+1,5 \mathrm{SDi}$ & Layak \\
3 & $\mathrm{Mi}-0,5 \mathrm{SDi}-\mathrm{Mi}+0,5 \mathrm{SDi}$ & Cukup Layak \\
4 & $\mathrm{Mi}-1,5 \mathrm{SDi}-\mathrm{Mi}-0,5 \mathrm{SDi}$ & Kurang Layak \\
5 & $\mathrm{Mi}-3 \mathrm{SDi}-\mathrm{Mi}-1,5 \mathrm{SDi}$ & Sangat Kurang Layak \\
\hline
\end{tabular}

(Dantes, 2017)

Selanjutnya untuk mengukur kepraktisan pada penelitian ini diperoleh dari hasil angket respon siswa sebagai pengguna produk berupa modul elektronik berbasis Education for Sustainable Development menggunakan flip PDF professional pada muatan pelajaran IPA tema lingkungan sahabat kita. Setelah data tersebut diperoleh, dianalisis dengan menggunakan rumus Mean observasi yaitu sebagai berikut.

$$
\mathrm{M}=\frac{\sum f X}{N}
$$

(Ananda \& Fadhli, 2018)
Keterangan :

$\mathrm{M}$ = nilai rata-rata atau Mean observasi

$\sum \mathrm{f} X=$ jumlah skor seluruh responden

$N$ = banyaknya responden

Perolehan skor dari masing-masing siswa dijumlahkan, selanjutnya dirataratakan untuk memperoleh hasil kepraktisan. Penentuan hasil kepraktisan dari modul elektronik dilakukan dengan membandingkan nilai rata-rata ke tabel pengkonfersian kategori PAIT (Penilaian Acuan Ideal Teoritik) sebagai berikut.

Tabel 3. Kategori PAIT

\begin{tabular}{cll}
\hline No & Kategori PAIT & Keterangan \\
\hline 1 & $\mathrm{Mi}+1,5 \mathrm{SDi}-\mathrm{Mi}+3 \mathrm{SDi}$ & Sangat Praktis \\
2 & $\mathrm{Mi}+0,5 \mathrm{SDi}-\mathrm{Mi}+1,5 \mathrm{SDi}$ & Praktis \\
3 & $\mathrm{Mi}-0,5 \mathrm{SDi}-\mathrm{Mi}+0,5 \mathrm{SDi}$ & Cukup Praktis \\
4 & $\mathrm{Mi}-1,5 \mathrm{SDi}-\mathrm{Mi}-0,5 \mathrm{SDi}$ & Kurang Praktis \\
5 & $\mathrm{Mi}-3 \mathrm{SDi}-\mathrm{Mi}-1,5 \mathrm{SDi}$ & Sangat Kurang Praktis \\
\hline
\end{tabular}

(Dantes, 2017)

\section{HASIL DAN PEMBAHASAN}

Hasil dari penelitian ini adalah produk berupa modul elektronik berbasis Education for Sustainable Development menggunakan flip PDF professional pada muatan pelajaran IPA tema lingkungan sahabat kita untuk siswa kelas V. Modul elektronik ini dibuat agar menampilkan gambar, animasi, video, dan audio sehingga menarik siswa mempelajarinya. Selain itu, juga dapat mengembangkan keterampilan siswa agar memiliki nilai-nilai yang berkelanjutan melalui upaya memunculkan konsep Education for Sustainable Development pada teks informasi maupun tugas. Pengembangan modul elektronik ini dilakukan melalui analyze, design, development, dan evaluation.

Tahap analyze ditempuh melalui pengumpulan data dan informasi hasil analisis kebutuhan yakni mengetahui bagaimana kondisi sekolah dan pembelajaran di kelas serta bahan ajar yang digunakan guru, analisis kurikulum mengetahui penerapan pendidikan berorientasi lingkungan serta KD dan IPK untuk mengembangkan modul elektronik, analisis karakteristik siswa dilakukan agar pengembangan modul elektronik dapat 
sesuai dengan kemampuan akademik dan tahap perkembangannya, dan juga dilakukan analisis modul elektronik untuk mendapatkan kriteria modul yang baik.

Tahap design diawali dengan pemilihan program aplikasi, selanjutnya dilakukan perancangan konten dan komposisi setiap halaman pada modul elektronik menggunakan storyboard. Selain itu, juga dilakukan perancangan instrumen untuk menguji modul elektronik.

Tahap development dilakukan dengan merealisasikan modul elektronik yang telah dirancang sesuai storyboard. Modul elektronik yang dikembangkan juga memuat aspek dari pendekatan konsep Education for Sustainable Development yang disisipkan pada materi, informasi, tugas atau latihan. Selain merealisasikan modul elektronik yang telah dirancang juga dilakukan validasi instrumen oleh para ahli sebelum digunakan menjadi angket validasi produk ahli, angket respon guru, dan angket respon siswa, sehingga dapat digunakan mengukur validitas dan kepraktisan dari modul elektronik.

Tahap evaluation pada penelitian ini adalah melakukan penilaian dari keseluruhan tahapan yang dilaksanakan. Evaluasi pada tahap analyze dilaksanakan dalam analisis kebutuhan dan kurikulum. Evaluasi pada tahap design berupa perbaikan storyboard dan perbaikan rancangan instrumen. Evaluasi dalam tahap development dilakukan revisi atau perbaikan pada instrumen yang telah dirancang dan modul elektronik.

Seluruh instrumen yang telah disusun dilakukan uji validitas isi sebelum instrumen nantinya digunakan sebagai angket untuk menguji modul elektronik. Hasil dari validitas isi diperoleh bahwa keseluruhan instrumen mendapatkan nilai 1,0 pada kategori yakni sangat tinggi. Selanjutnya instrumen tersebut dijadikan angket validasi produk ahli materi pembelajaran, angket validasi produk ahli desain pembelajaran, angket validasi produk ahli materi pembelajaran, angket respon guru, dan angket respon siswa. Adapun hasil perhitungan validitas produk oleh ahli materi pembelajaran, ahli desain pembelajaran, dan juga ahli media pembelajaran diuraikan pada tabel berikut.

Tabel 4. Hasil validitas produk oleh ahli

\begin{tabular}{ccccc}
\hline No. & \multicolumn{1}{c}{ Ahli } & Persentase & Rerata Persentase & Kategori \\
\hline 1. & Ahli Materi Pembelajaran I & $100 \%$ & \multirow{2}{*}{$97,14 \%$} & Sangat Layak \\
& Ahli Materi Pembelajaran II & $94,28 \%$ & & \\
2. & Ahli Desain Pembelajaran I & $96 \%$ & $97 \%$ & Sangat Layak \\
& Ahli Desain Pembelajaran II & $98 \%$ & & \\
3. & Ahli Media Pembelajaran I & $96 \%$ & \multirow{2}{*}{ Sangat Layak } \\
\hline
\end{tabular}

Merujuk uraian pada tabel tersebut, dapat diketahui bahwa hasil validitas produk dari 2 ahli materi pembelajaran berada pada kategori sangat layak, sehingga menunjukkan bahwa modul elektronik dalam penelitian ini tergolong valid. Hal tersebut berdasarkan pada penilaian aspek dan indikator bahwa cakupan materi dalam modul elektronik mudah dipahami dan konten sesuai dengan perkembangan siswa yang artinya sudah sesuai dengan tuntutan kompetensi inti, kompetensi dasar, dan juga indikator pencapaian kompetensi dengan tujuan pembelajaran yang jelas. Pernyataan tersebut sejalan bahwa kesesuaian isi materi dengan tujuan pembelajaran dalam modul elektronik perlu untuk memperhatikan kompetensi dan indikator, karena tujuan yang jelas akan menjadi acuan dalam setiap proses pembelajaran (Hastari et al., 2019).

Selanjutnya, hasil validitas produk dari 2 ahli desain pembelajaran juga berada pada kategori sangat layak, sehingga menunjukkan bahwa modul elektronik dalam penelitian ini tergolong valid. Berdasarkan pada penilaian aspek dan indikator disampaikan bahwa modul elektronik yang dikembangkan sudah 
adanya pemberian multimedia seperti gambar, animasi, audio, serta video, sehingga dapat membuat penyampaian materi menjadi lebih konkret. Tentunya hal tersebut memicu ketertarikan dan keterlibatan siswa dalam belajar dan tidak hanya mengandalkan aspek teks. Multimedia menyediakan banyak pilihan untuk dapat belajar secara kreatif dan juga memfasilitasi pembelajaran melalui penyampaian materi yang lebih interaktif (Shilpa \& Sunita, 2016).

Kemudian, hasil validitas produk dari 2 ahli media pembelajaran berada pada kategori sangat layak juga menunjukkan bahwa modul elektronik dalam penelitian ini tergolong valid. Berdasarkan pada penilaian aspek dan indikator disampaikan bahwa bahwa setiap halaman modul elektronik mudah dicari karena tampilan navigator disajikan sangat sederhana dan mudah dipahami sebab ikon navigator berbentuk gambar dengan keterangan bahasa yang jelas. Penggunaan ikon pada modul elektronik dengan menggunakan gambar akan mudah diingat pengguna yang secara tidak langsung menjelaskan fungsi navigasi (Winatha et al., 2018).

Pengujian validitas empirik dilakukan dengan Product Moment untuk mengetahui validitas konsistensi internal butir angket respon guru dan menghitung nilai Mean observasi. Hasil analisis dengan Product Moment menunjukkan bahwa seluruh butir pernyataan pada angket respon guru yang berjumlah 70 butir memiliki nilai $r_{\text {hitung }}$ di antara 0,644 sampai 0,915 . Ini menunjukkan jika $r_{\text {hitung }}$ lebih besar dari $r_{\text {tabel }}=0,632 \quad\left(r_{\text {hitung }}>r_{\text {tabel }}\right)$ dengan nilai $\alpha=0,05$. Maka, dapat disimpulkan bahwa seluruh butir pernyataan pada angket respon guru tersebut dapat digunakan untuk memperoleh data validitas empirik dari produk berupa modul elektronik berbasis Education for Sustainable Development menggunakan flip PDF professional untuk siswa kelas V.

Selanjutnya untuk mengetahui hasil dari validitas empirik dari produk berupa modul elektronik pada penelitian ini, dilakukan dengan membandingkan perhitungan nilai Mean observasi ke tabel pengkonfersian berdasarkan kategori PAIT. Berdasarkan dari hasil analisis yang dilakukan, maka didapatkan bahwa nilai Mean observasi adalah sebesar 328,3. Jika nilai Mean observasi tersebut dibandingkan dalam tabel kategori PAIT, maka nilai tersebut berada pada kategori sangat layak yang dapat diartikan bahwa modul elektronik tergolong valid. Hal tersebut disebabkan karena modul elektronik menggunakan bahasa yang sesuai dengan tingkat perkembangan siswa dan materi yang disajikan bersifat kontekstual. Dalam mengembangkan modul elektronik pendekatan yang dianggap paling sesuai adalah pendekatan kontekstual, karena mengaitkan materi dengan situasi dunia nyata, sehingga siswa dapat membuat hubungan antara pengetahuan dengan penerapannya dalam kehidupan seharihari (Febriana \& Sakti, 2021).

Hasil uji kepraktisan modul elektronik diperoleh dari hasil pengisian angket respon siswa yang berupa skor, dianalisis dengan membandingkan nilai Mean observasi ke tabel pengkonfersian berdasarkan kategori PAIT. Berdasarkan analisis, diperoleh bahwa nilai Mean observasi sebesar 174,64. Nilai tersebut dibandingkan dalam tabel kategori PAIT dan berada pada kategori sangat praktis yang dapat diartikan bahwa modul elektronik berbasis Education for Sustainable Development menggunakan flip PDF professional pada muatan pelajaran IPA tema lingkungan sahabat kita untuk siswa kelas $\mathrm{V}$ tergolong praktis. Hal tersebut disebabkan karena adanya petunjuk yang jelas dan modul elektronik dapat digunakan secara fleksibel. Modul elektronik penggunaannya tidak dibatasi tempat dan waktu, sehingga membantu siswa mengukur dan mengontrol kemampuan dan intensitas belajar tergantung kesanggupannya (Laili et al., 2019).

Nilai yang tergolong valid dan praktis dari hasil pengujian validitas dan kepraktisan terhadap modul elektronik berbasis Education for Sustainable Development menggunakan flip PDF professional pada muatan pelajaran IPA 
pelajaran IPA tema lingkungan sahabat kita untuk siswa kelas $\mathrm{V}$ dari penelitian ini adalah memberikan rujukan bahwa saat ini sudah sangat memungkinkan untuk dilakukannya pengembangan modul secara elektronik terutama bagi siswa pada jenjang sekolah dasar. Karena siswa telah mampu menggunakan perangkat komputer atau laptop dan smartphone sebagai media dalam belajar. Secara positif bahwa smartphone dapat membantu mereka untuk mencari dan menggunakan sumber belajar elektronik maupun digital (Salehudin et al., 2020).

Selain beberapa hasil temuan baru tersebut, terdapat beberapa keterbatasan penelitian ini diantaranya pelaksanaan tahap implementation tidak dapat terlaksana karena adanya keterbatasan waktu peneliti. Selanjutnya, berkaitan dengan modul elektronik hanya dapat dijalankan dengan program aplikasi flip PDF professional, maka jika modul elektronik ingin dipelajari dalam keadaan offline tidak dapat digunakan pada smartphone dan harus menginstal program aplikasi flip PDF professional pada PC atau laptop pengguna.

Implikasi dari penelitian ini adalah (1) modul elektronik yang dikembangkan ini dapat dimanfaatkan pada pembelajaran khususnya dengan muatan pelajaran IPA pada materi siklus air, (2) modul elektronik ini menjadikan pembelajaran lebih dapat berpusat pada siswa, (3) modul elektronik dapat memotivasi siswa untuk belajar karena terlibat secara langsung dengan aktivitas-aktivitas belajar, (4) modul elektronik ini dapat menjadikan siswa terbiasa menghubungkan materi dengan kehidupannya sehari-hari, (5) tersedianya penilaian diri dan evaluasi pembelajaran pada modul elektronik, sehingga siswa dapat mengetahui pencapaian hasil belajar mereka, dan (6) modul elektronik ini dapat mendorong guru menguasai ICT.

\section{PENUTUP}

Berdasarkan dari hasil penelitian dan juga pembahasan, uraian simpulan penelitian ini yaitu: (1) Pengembangan modul elektronik berbasis Education for Sustainable Development menggunakan 
pelajaran lain, (3) lembaga pendidikan agar dapat meningkatkan sarana prasarana seperti PC atau laptop dan internet.

\section{DAFTAR PUSTAKA}

Ananda, R., \& Fadhli, M. (2018). Statistik Pendidikan (Teori dan Praktik dalam Pendidikan). CV. Widya Puspita.

Apsari, P. N., \& Rizki, S. (2018). Media Pembelajaran Matematika Berbasis Android pada Materi Program Linear. Jurnal Pendidikan Matematika, 7(1). https://ojs.fkip.ummetro.ac.id/index.ph $\mathrm{p} / \mathrm{matematika/article/view/1357}$

Avikasari, R., \& Indriayu, M. (2018). Keefektifan Penggunaan Bahan Ajar Science Literacy Terhadap Peningkatan Prestasi Belajar. Jurnal Kependidikan, 2(2). https://journal.uny.ac.id/index.php/jk/a rticle/view/19167/pdf

Candiasa, I. M. (2011). Pengujian Instrumen Penelitian disertai Aplikasi ITEMAN dan Bigstep. Universitas Pendidikan Ganesha.

Dantes, N. (2017). Asesmen dan Evaluasi Pembelajaran. Undiksha Press.

Dularip. (2020). Pengembangan Bahan Ajar Berbasis ESD pada Mata Pelajaran IPS untuk Meningkatkan Karakter Cinta Lingkungan Hidup Siswa di SMP. Jurnal Education and Development, 8(4). http://journal.ipts.ac.id/index.php/ED/ article/view/2066/1080

Febriana, F. D., \& Sakti, N. C. (2020). Pengembangan E-Modul Berbasis Kontekstual Sebagai. JURNAL PROFIT: Kajian Pendidikan Ekonomi Dan IImu Ekonomi, 8(1), 47-58.

Feriyanti, N. (2019). Pengembangan EModul Matematika Untuk Siswa SD. Teknologi Pendidikan Dan Pembelajaran, 1, 1-12.

Haspen, C. D. T., \& Festiyed. (2019). Meta-Analisis Pengembangan EModul Berbasis Inkuiri Terbimbing Pada Pembelajaran Fisika. Jurnal Penelitian Pembelajaran Fisika, 5(2), 
180-187.

Hastari, G. A. W., Agung, A. A. G., \& Sudarma, I. K. (2019). Pengembangan Modul Elektronik Berpendekatan Kontekstual Pada Mata Pelajaran IImu Pengetahuan Sosial Kelas Viii Sekolah Menengah Pertama. EDUTECH Universitas Pendidikan Ganesha, 7, 33-43.

Indrati, D. A., \& Hariadi. (2016). ESD (Education for Sustainable Development) Melalui Pembelajaran Biologi. Prosiding Symbion Prodi Pendidikan Biologi, FKIP, Universitas Ahmad Dahlan.

KNIU. (2014). Pendidikan untuk Pembangunan Berkelanjutan (Education for Sustainable Development) di Indonesia Implementasi dan Kisah Sukses. Kemendikbud.

Laili, I., Ganefri, \& Usmeldi. (2019). Efektivitas Pengembangan E-Modul Project Based Learning Pada Mata Pelajaran Instalasi. Jurnal Imiah Pendidikan Dan Pembelajaran, 3, 306-315.

https://ejournal.undiksha.ac.id/index.p $\mathrm{hp} / \mathrm{JIPP} /$ article/download/21840/1351 3

Nikmah, I. L. (2018). Pengembangan Bahan Matematika SMA Berbasis Tujuan Education for Sustainable Development untuk Meningkatkan Kemampuan Pemecahan Masalah dan Disposisi Matematis. Universitas Pendidikan Indonesia.

OECD. (2018). PISA 2018 Results Combined Executive Summaries: Vols. I, II, III. Database.

Rahman, A., Heryanti, L. M., \& Ekanara, B. (2019). Pengembangan Modul Berbasis Education for Sustainable Development pada Konsep Ekologi untuk Siswa Kelas X SMA. Jurnal Eksakta Pendidikan (Jep), 3(1), 1. https://doi.org/10.24036/jep/vol3iss $1 / 273$

Salehudin, M., Marniah, \& Hariati. (2020). Siswa SD Menggunakan Smartphone
Dalam Pembelajaran Online. IBTIDA': Media Komunikasi Hasil Penelitian Pendidikan Guru Madrasah Ibtidaiyah, 01(02), 229-241. https://doi.org/10.37850/ibtida

Seruni, R., Munawaroh, S., Kurniadewi, F., Nurjayadi, M., Kimia, M. P., Matematika, F., Alam, P., Jakarta, N., Muka, J. R., Rw, R. T., \& Gadung, P. (2019). Pada Materi Metabolisme Lipid Menggunakan Flip Pdf Professional. Jurnal Tadris Kimiya, 4(1), 48-56.

Shilpa, S., \& Sunita, M. (2016). A Study an Interactive Elementary Education ( 36 ) With Multimedia. International Journal of Home Science, 2(1), 214215.

https://www.homesciencejournal.com/ archives/2016/vol2issue1/PartD/2-144-761.pdf

Sriwahyuni, I., Risdianto, E., \& Johan, $H$. (2019). Pengembangan Bahan Ajar Elektronik Menggunakan Flip Pdf Professional Pada Materi Alat-Alat Optik Di Sma. Jurnal Kumparan Fisika, 2(3), 145-152. https://doi.org/10.33369/jkf.2.3.145152

Sugiyono. (2015). Metode Penelitian Kuantittatif Kualitatif dan R\&D. Alfabeta.

Suwarto, R. S. (2021). Implementasi Education for Sustainable Development dan Pencapaian Sustainability Consciousness Siswa di Sekolah Adiwiyata dan Sekolah Berbasis ESD. Universitas Pendidikan Indonesia.

Winatha, K. R. (2018). Pengembangan Emodul Interaktif Berbasis Proyek Mata Pelajaran Simulasi Digital. Jurnal Pendidikan Teknologi Dan Kejuruan, 15(2), 188-199. https://doi.org/10.23887/jptkundiksha.v15i2.14021

Windyariani, S. (2019). Pembelajaran Berbasis Konteks dan Kreativitas (Strategi untuk Membelajarkan Sains di Abad 21). Deepublish. 
Zulfahrin, L. (2019). Pengembangan EModul Kimia Berbasis Problem Based Learning (PBL) untuk Meningkatkan Pemahaman Konsep Siswa. Universitas Negeri Semarang. 